\section{Does Board Diversity Matter for the Quality of CSR Disclosure? Evidence from the Financial Sector of Pakistan}

\author{
Ismail Khan ${ }^{1}$ \\ Iftikhar Khan ${ }^{2}$ \\ Muhammad Asim Afridi ${ }^{2}$
}

\begin{abstract}
Purpose - This study aims to examine the influence of board diversity on the quality of CSR disclosure (QCSR) and propose that this relationship is patterned differently in different contexts and nations, due to their distinctive characteristics.

Design/methodology/approach - The resource-based view (RBV) theory is used to evaluate the hypothesized relationship through an empirical investigation of 64 Pakistani financial firms, by applying a random-effects regression and the generalized method of moments (GMM).]

Findings - The findings indicate that age, gender, educational level, and educational background diversities positively influence QCSR disclosure. However, nationality, ethnic, and tenure diversities have no significant relationship with QCSR disclosure. The results were further checked by a robust regression and sensitivity analysis.

Originality/value - Using RBV theory, this paper provides an additional contribution concerning the role played by board diversity in a firm's strategic performance, particularly CSR disclosure. The article contributes to the literature by finding that there is no unanimous rule for board diversity supporting CSR, due to the unique characteristics of different jurisdictions and institutional contexts.
\end{abstract}

Keywords - Corporate Governance; Board Diversity; Quality of CSR Disclosure; Resource-Based View (RBV) Theory

1. Department of Management Sunway University Business School, Selangor, Malaysia

2. COMSATS University Islamabad, Abbottabad, Pakistan

How to cite:

Khan, I., Khan, I., Asim Afridi, A. (2021). Does Board Diversity Matter for the Quality of CSR Disclosure? Evidence from the Financial Sector of Pakistan. Revista Brasileira de Gestão de Negócios, 23 (1), p.104-126.
Received on:

11/30/2019

Approved on:

09/08/2020

Responsible Editor:

Prof. Dr. João Mauricio Gama

Boaventura

\section{Evaluation process:}

Double Blind Review

\section{Reviewers:}

Flavia Donadelli; One of the reviewers decided not to disclose his/her identity.

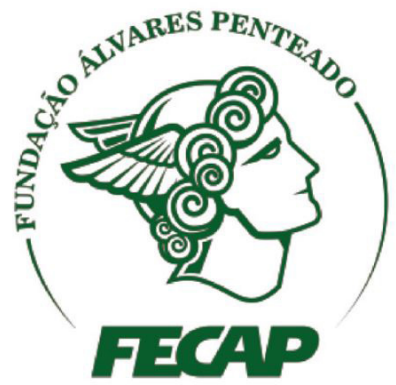

Revista Brasileira de Gestáo de Negócios

https://doi.org/10.7819/rbgn.v23i1.4091 


\section{Introduction}

Recent corporate scandal, failures, business complexities, corruption, and global competition have shown that an overemphasis on stockholder wealth maximization while ignoring other aspects of a business results in failure and poor performance. Thus, corporate social responsibility and CSR disclosure are concepts that have gained strategic importance (Hunjra, Mehmood, \& Tayachi, 2020), and have become a priority issue for firms globally (Baraibar-Diez \& Sotorrio, 2018). CSR disclosure is communication between corporations and users (stakeholders) of annual reports regarding firms' engagement in CSR practices (Katmon, Mohamad, Norwani, \& Al Farooque 2019; Saleh, Zulkifli, \& Muhamad 2010)i. Researchers strongly believe that firms should not be judged just on their economic success but also on their contribution to society as a whole (Wellalage, Locke, \& Acharya, 2018). Firms disclose CSR information to be more transparent and accountable (Barroso, Villegas, $\&$ Perez-Calero, 2011), and achieve a competitive edge in the global business environment (Khan, Khan, \& Senturk, 2019b). Moreover, it enhances a firm's reputation (Axjonow, Ernstberger, \& Pott, 2018), corporate legitimacy (Azim, 2016), and regulation compliance (Chuang \& Huang, 2016), and it improves corporate financial performance (Platonova, Asutay, Dixon, \& Mohammad, 2018). Despite its importance, recent studies on CSR disclosure in the developing country context demonstrate that the quantity and quality of CSR disclosure are still low (Katmon et al., 2019; Mehjabeen \& Bukth, 2020; Nour, Sharabati, \& Hammad, 2020). Hence, it is important to identify the main barriers preventing financial firms from engaging in quality CSR disclosure, and one important area for consideration is the way firms are governed (Hunjra et al., 2020).

Good corporate governance aligns stakeholders' interests (Harjoto, Laksmana, \& Yang, 2019) and stakeholders influence the implementation of firms' strategies (Elias, 2019). Corporate governance in the financial sector is particularly important (Aldaas, Mohammad, \& Abuhashesh, 2019; Elyasiani, \& Zhang, 2015) because financial firms act as financial intermediaries and are essential for driving economic practices, with consequences for the social environment (Abdelbadie \& Salama, 2019; Gangi, Meles, D’Angelo, \& Daniele, 2019). Boards of directors, which are the cornerstone of governance frameworks (Rao \& Tilt, 2016a; Manyaga \& Taha, 2020), play an important role in making strategic decisions (Liang, Chang, \& Liu, 2020) and have become more inclined to invest in CSR activities (Chang, Oh, Park, \& Jang, 2017). Corporate boards are arguably obligated to set CSR agendas and develop strategies for achieving competitive advantages and sustainable corporate operations (Jizi, 2017). Thus, board composition determines firms' economic, social, ethical, and environmentally responsible behaviors (Khan et al., 2019a; Michelon \& Parbonetti, 2012) and can improve transparency by increasing the disclosure of CSR practices (Baraibar-Diez \& Sotorrio, 2018).

Among the various aspects of board composition, board diversity is particularly relevant for the firm's economic success (Manyaga \& Taha, 2020), competitive performance (Triguero-Sanchez, Pena-Vinces, \& Guillen, 2018), and CSR performance (Harjoto, Laksmana, \& Lee, 2015; Yusof, Nordin, Jais, \& Sahari, 2019). However, board diversity and CSR disclosure are quite surprisingly ignored in the financial sector and only studied in the non-financial sector (Al-Fadli, Sands, Jones, Beattie, \& Pensiero, 2019; Harjoto et al., 2019; Hunjra et al., 2020; Katmon et al., 2019; Khan et al., 2019a; Muttakin, Khan, \& Subramaniam, 2015; Pucheta-Martinez \& Gallego-Alvarez, 2019; Rao \& Tilt, 2016b). Also, no study has yet been conducted in a developing nation, in particular Pakistan, which has empirically examined the impact of board diversity on CSR disclosure in the financial sector. Moreover, the disclosure requirements for financial firms are different to those for non-financial firms (Al-Fadli et al., 2019; Al-Rahahleh, 2017). According to Liang et al. (2020), the proliferation of CSR has become very important in the financial sector. Therefore, an attempt is made here to examine the QCSR disclosure practices and the influence of board diversity on QCSR disclosure in the financial sector of Pakistan.

We contribute to the literature in different ways. First, the findings improve our knowledge about both board diversity and QCSR disclosure in the financial sector in a developing country context. The majority of the research findings on board diversity and CSR disclosure focus on developed economy non-financial firms (Harjoto et al., 2015; Harjoto et al., 2019; Jizi, 2017; Rao \& Tilt, 2016b), while we provide evidence from a developing economy, particularly Pakistani financial firms, where this topic is not well researched. Second, the results of the study may be similar for other developing nations where the regulators and policy-makers take particular attention in designing CSR-led business strategies for financial sectors to improve competitiveness. Third, and most notably, the existing studies (e.g. on both financial and non-financial firms) mostly focus on resource dependency theory, agency 
theory, stakeholder theory, legitimacy theory, etc. (Abdullah \& Ismail, 2013; Barako \& Brown, 2008; Chang et al., 2017; Harjoto et al., 2019; Hassan et al., 2020; Yusof et al., 2019), and none of these studies have provided evidence based on the resource-based view (RBV) theory. We make a contribution to the theoretical literature by examining the board diversity and CSR relationship in a developing economy from the perspective of RBV theory.

The remainder of this paper proceeds as follows. The next section provides a brief literature review, which is followed by the research design. Afterword, the results and discussion are documented, before we present the conclusion in the final section.

\section{Literature Review}

Recently, strategic management researchers have focused on looking into why some corporations are regularly more profitable than others (Barney \& Clark, 2007). One approach is to seek competitive advantages inside the organization, particularly in its internal resources (Fraczkiewicz-Wronka \& Szymaniec, 2012). The term resource-based view (RBV) was first coined by Wernerfelt (1984), who contends that a firm's resources comprise tangible and intangible assets (Galbreath, 2005; Wernerfelt, 1984) $)^{\text {ii }}$. RBV theory focuses on the resources owned by firms (Fraczkiewicz-Wronka \& Szymaniec, 2012) and is most relevant when studying firms' resources (Frynas \& Yamahaki, 2016). According to RBV theory, firms delineate their strategies by managing their internal resources in relation to their social and environmental circumstances to achieve sustained competitive advantages (Barney, 1991). The internal resources of a firm that are valuable, rare, inimitable, or non-substitutable by other firms can lead to sustainable competitive advantages (e.g., Barney, 1991; Wernerfelt, 1984).

The sources of sustainable competitive advantages have received considerable attention (Barney, 1991; King, 2007). In the recent corporate governance literature, board diversity as a firm's internal resource has become a significant issue of debate for researchers, academia, and policymakers (Hassan et al., 2020; Katmon et al., 2019; Olthuis \& Oever, 2020). The resource-based view (RBV) suggests that firms' competitive advantages and superior performance are closely related to their internal resources and capabilities (Barney 1991; Peteraf \& Bergen, 2003). Therefore, the importance of board diversity can be highlighted through the theoretical lens of resource- based view (RBV) theory (Barney, 1991; Galbreath, 2005; Yu \& Choi, 2016), whereby as a part of firms' strategic decisions, board diversity improves core organizational competencies (Hamel \& Prahared, 1994) and dynamic internal capability (Teece, Pisano, Shuen, 1997), thereby increasing overall firm capability (Katmon et al., 2019). Diversity includes attributes such as age, ethnicity, cultural diversity, and religion (Jonson, McGuire, Rasel, \& Cooper, 2020), gender, education, skill, expertise, and various preferences (political and sexual preference), etc. (Ayuso \& Argandona, 2007; Hassan et al., 2020). Diverse board members provide a variety of skills and expertise (Jonson et al., 2020) and are able to make hypercritical decisions compared to a homogeneous board (Zhang et al., 2013). Thus, firms have required heterogeneous boards to improve competitive advantages (Galbreath, 2016) and offer a diverse perspective when making strategic decisions, such as those regarding CSR (Rao \& Tilt, 2016a).

Board diversity is the main strategic resource concerning CSR disclosure (Hassan et al., 2020; Khan et al., 2019b) and improves firms' competitiveness (Katmon et al., 2019). Many theoreticians contend that board diversity leads to a stakeholder orientation, involving ethical practices and socially responsible behavior to reduce unexpected consequences (Adams \& Ferreira, 2009; Carter, D’Souza, Simkins, \& Simpson, 2010). The stakeholder approach to strategic management suggests that management needs to develop and implement strategies that satisfy the different groups of stakeholders (Elias, Cavana, \& Jackson, 2002; Freeman, Harrison, \& Zyglidopoulos, 2018). Strategies that oppose stakeholders' social value put the firm's economic success at stake as the stakeholders are more likely to respond negatively to the firm and vice versa (Maurer, Bansal, \& Crossan, 2011). Management has to deal with the task of balancing the needs of stakeholders holding diverse world views (Elias, 2012). Board diversity is not merely an economics-driven resource. Stakeholder and boarder societal accountability perspectives call for diversity and communication/accountability (Harjoto et al., 2019; Katmon et al., 2019). Consequently, diversity is one of the strategic capabilities under the lens of RBV theory (Maurer et al., 2011). To compete in today's complex business network, building a strong mutual relationship with stakeholders is more crucial (Fisman, Heal, \& Nair, 2005) as different stakeholder groups require different management behavior (Elias \& Davis, 2018). Firms may develop a strong mutual relationship with various groups of stakeholders (Freeman, Wicks, \& Parmar, 2004) through 
satisfactory CSR practices guided by board member diversity (Harjoto et al., 2019), leading to a strategic approach that improves corporate value (Freeman, 1984).

CSR disclosure is strongly influenced by stakeholders' values, interests, religion, race, preferences, and their other requirements (Chang et al., 2017; Harjoto et al., 2015), as the diverse stakeholders are the key to management strategies (Elias, 2012; Elias \& Mathew, 2015; Zwikael, Elias, \& Ahn, 2012). Firms meet different groups of stakeholders' requirements by practicing and reporting CSR activities (Gill, 2008; Kolk \& Pinkse, 2010). The board of directors is ultimately responsible for disclosure on CSR practices (El-Bassiouny \& El-Bassiouny, 2019). Therefore, board diversity as a strategic resource is more crucial for complex strategic decisions like CSR practices (Chang et al., 2017; Rao \& Tilt, 2016a). The considerable literature on board diversity and CSR focuses on the nonfinancial sector (Hassan et al., 2020; Hunjra et al., 2020; Katmon et al., 2019; Khan et al., 2019a; Muttakin et al., 2015; Nour et al., 2020). However, concerning financial firms' commitment to CSR disclosure, so far no studies have been conducted on the effect of board diversity on QCSR disclosure in developing economies, particularly in Pakistan. To fill the gap, this study therefore investigates the influence of board diversity on QCSR disclosure in the financial sector using the resource-based view (RBV) theory. Unlike previous studies that identify the limited scope of diversity (Carter et al., 2010; Hassan et al., 2020; Muttakin et al., 2015; Upadhyay \& Zeng, 2014; Yusof et al., 2019), our study covers seven diversity characteristics (i.e., age, gender, nationality, ethnicity, educational level, educational background, and tenure), which form the cognitive thinking of the corporate board and are hence worth investigating.

\section{Research Design}

The research methodology selection depends on the research paradigm, which guides the research design (McGregor \& Murnane, 2010; Walter, 2006). Thus, if the research paradigm is not first defined, there will be no effective alternative concerning the choice of methodology, methods, or research design (McGregor \& Murnane, 2010; Saunders, Lewis, \& Thornhill, 2009). The term "research paradigm" refers to the research philosophy regarding the social world, in terms of its set of beliefs or world view that inform the investigation (Kuhn, 1977; Ponterotto, 2005). In other words, the research paradigm affects the way knowledge is investigated and interpreted.
Researchers use different research paradigms, including positivism, post-positivism, constructivism, pragmatism, and transformativism, depending on the nature of the study (Mackenzie \& Knipe, 2006; Ponterotto, 2005). In line with existing studies, we used the positivism paradigm, based on the assumption that positivism is most likely applied if the reality is objectively given, apprehendable, identifiable, measurable, and quantifiable (Henning, Rensburg, \& Smit, 2004). The positivist paradigm in the form of philosophical realism requires and supports the quantitative methodology, with a deductive approach that is objective (Cacioppo, Semin, \& Berntson, 2004) and related to general effects and causal explanations (Marczyk \& DeMatteo, 2005; Sarantakos, 2005).

The previous studies also show that research that applies the positivist paradigm tends to primarily apply the quantitative methodology to the data and analysis (Cohen \& Manion, 1994; Silverman, 2000). In terms of methodology, the truth in the positivist paradigm is achieved through the use of statistical tools and measurements (Kim, 2003). In contrast, the qualitative studies focus on a relativist, constructive ontology, positing that there is no objective reality (Krauss, 2005). We applied a positivist paradigm, an empirical, quantitative methodology that uses a deductive approach, and the methods of sampling, data gathering, reporting the results, analyzing the evidence, and presenting the findings (McGregor \& Murnane, 2010).

The sample consists of all financial firms listed on the Pakistan Stock Exchange (PSX). We excluded those firms with missing, unpublished, or incomplete information. The reason for choosing these firms as a sample is due to the dearth of empirical research in this area and their relative importance in the Pakistani economy, ranking first in terms of business volume and shares traded (PSX, 2018). We used multiple data collection sources in addition to different corporate governance institutes, CSR reporting, and award centers $\mathrm{s}^{\mathrm{iii}}$. The financial and board data were collected from the press, firm websites, annual reports, and sustainability reports. Social and environmental information was collected from corporate governance reports, directors' reports, chairmen's statements, and CSR sustainability reports.

The data collection was based on two conditions to conduct the empirical estimation. First, the firms must have been registered with the stock exchange from 2010. As a pilot study, the CSR reporting practices of financial firms listed on the PSX were checked and it was observed that the phenomena of CSR reporting started in 2010 in 
the majority of firms. Therefore, we selected 2010 as the base year. Second, keeping in view the CSR disclosure of early practices in the case of Pakistan, no additional bar on data gathering was put in place. However, to keep the sample to a reasonable size, firms that produced at least three years of CSR reports were considered. Thus, the resulting sample consists of 64 financial firms with 576 firm-year observations covering 2010 to 2018 .

It is essential for any research to choose a suitable research method that provides a solution to the research problem investigated (Abdullah \& Raman, 2001). The time constraints and resource constraints affect the adoption of the research methodology in its pure form (Sieber, 1973). The suitability of the research method depends on the "efficiency and informational adequacy" of the methods used in gathering the data (Vulliamy, 1990). Following Katmon et al. (2019), we used the measurement process that encompasses the "content analysis" approach, measuring both quantitative and qualitative information disclosure related to the CSR framework (i.e. community, employee, environment, and product).

The integration of both quantitative and qualitative measures in research studies is worthwhile (Sieber, 1973) as each measure is strengthened by the other (Abdullah \& Raman, 2001). We note that our measurement approach is superior to the simple quantitative scoring approach (i.e. dichotomous scoring process: " 1 " if a firm discloses certain items in the index, and "0" otherwise) applied in existing studies (Ibrahim \& Hanefah, 2016; Khan, Muttakin, \& Siddiqui, 2013; Muttakin et al., 2015; Rao $\&$ Tilt, 2016b) in the sense that it goes beyond simple quantitative measurement and makes a subjective assessment of qualitative plus narrative information disclosure after reading the published reports (Al-Tuwaijri, Christensen, $\&$ Hughes, 2004).

\section{Variable Measurement}

\section{I Constructing the CSR measures}

Quality of CSR disclosure (QCSR) is used as the dependent variable, covering quantitative, qualitative, and narrative information. The technique of content analysis is used to measure the QCSR disclosure index. In line with Saleh et al. (2010), there are 20 items of QCSR disclosure classified into four categories, as shown in Appendix A. The score is calculated as the firm's obtained score divided by the total possible maximum score, which is 60 (Katmon et al., 2019). The weights are assigned to different disclosed items in the index based on the perceived importance of each item to a variety of user groups (Al-Tuwaijri et al., 2004). The reason for using this index is because, throughout this procedure, the researcher has to re-evaluate the quality of CSR disclosure based on the following four criteria:

a) quantitative CSR disclosure that contains financial information is assigned the highest weight of " 3 ";

b) qualitative disclosure containing non-quantitative CSR disclosure with particular information is assigned the weight of " 2 ";

c) qualitative disclosure containing only generic CSR-related information is assigned the lowest weight of "1";

d) those firms that do not disclose any CSR practices in their annual reports are assigned the lowest weight of " 0 " to a particular item in the index.

\subsection{Constructing the board diversity measures}

The study used the Blau index $(1977)^{\mathrm{iv}}$ to measure the diversity variables, comprising age, gender, nationality, ethnicity, educational level, educational background, and tenure, consistently with prior studies on board diversity (Abdullah \& Ismail, 2013; Barako \& Brown, 2008; Hafsi \& Turgut, 2013; Hassan et al., 2020; Harjoto et al., 2019; Hoang, Abeysekera, \& Ma, 2018; Upadhyay et al., 2014; Yusof et al., 2019;). AGE is a diversity index with three categories: 40 years old, 50 years old, and more than 50 years old ${ }^{v}$. GENDER is a heterogeneity index with two categories: male and female. NATIONALITY is a heterogeneity index with two categories: Pakistani and foreigner. Traditionally, ethnic diversity in Pakistan has been defined in terms of the four historical "nationalities," Punjabi, Sindhi, Pashtuns, and Balochi (Ahmed, 1996; Bhatti, Uddin, Ahmed, \& Bugert, 2010), with their cultural diversities (Khan, 1999; Majeed, 2010). These groups are unique in terms of language, place of origin, cultural activities, values, habits, health beliefs, and behavior (Jafar et al., 2003). Thus, ETHNICITY is a heterogeneity index with five ethnic groups: Punjabi, Sandhi, Balochi, Pashtuns, and others. EDULEVEL is a heterogeneity index with four educational levels: Ph.D., MS/M. Phil, master's degree, and diploma, and others. EDUBGROUND is a heterogeneity index with six categories: HRM, accountancy, banking and finance, economics, engineering, and law, and others. TENURE 
is a heterogeneity index for tenure diversity with five categories: less than 3 years (on average, a director's term lasts 3 years), 6, 9, 12, and 15 years or more.

\subsection{Control variables}

We found in the existing literature a set of control variables significantly affecting CSR activities. The control variables which are found to be related to CSR practices included board characteristics such as corporate board size. A larger board increases the effectiveness of a firm's disclosure as there are more members (Yusof et al., 2019). We also control for board independence and board meetings (Nour et al., 2020). Concerning audit committee characteristics, we include audit committee size (Khan et al., 2013), audit committee meetings (Khan et al., 2019b), and audit committee independence (Katmon et al., 2019). Khan et al. (2013) found that a large audit committee would be able to improve the CSR disclosure as it played a major role in monitoring the firm's management. In respect of firm-specific characteristics, we take into account the firm's size (Muttakin et al., 2015), leverage, and loss (Ajaz, Shenbei, \& Sarfraz, 2020; Lan, Wang, \& Zhang, 2013), and BIG4 audit quality (Hassan et al., 2020). Larger firms come under greater pressure from stakeholders and tend to report on CSR practices to legitimize their business (Bonson \& Bednarova, 2014). Audit quality improves the quality of information disclosure (Katmon et al., 2019). We also control for industry effects to understand the firms' motives of CSR disclosure, and for year effects to control for fixed year effects (Al-Fadli et al., 2019).

BODSIZE is the number of directors on the board. BODMEET is the frequency of board meetings held in a particular year. BODIND is the board's independence, calculated as the total number of independent directors divided by the total board members. ACSIZE is the total membership of the audit committee. ACMEET is the frequency of total audit committee meetings held in a year. ACIND is the audit committee's independence, calculated as the independent members in the audit committee divided by the total members in the audit committee. SIZE is the natural log of total market capitalization. LEV is the leverage, calculated as the total debt to equity ratio. BIG4 is the audit quality, measured using a dummy, which is " 1 " if the firm's annual report is audited by any one of the four big auditors, and "0" otherwise. LOSSCO is the firm's loss, measured using the dummy " 1 " if the company has negative earnings in a certain year and " 0 " for positive earnings. YEARDUMMY and INDUSTRYDUMMY are used to measure specific year and industry effects, respectively.

\section{Empirical Model}

The model developed below is applied to measure the influence of board diversity on QCSR disclosure. Researchers often use a Hausman test to guide their selection of either the Fixed Effects Model or Random Effects Model (Baltagi, 2005). The results of the Hausman test suggested the application of the REM. Prior studies have also used the REM for examining panel data on board diversity (Chang et al., 2017; Khan et al., 2019b). Unlike the REM, which can be generalized to the whole population of the study (i.e. all financial firms and not just this sample), the FEM cannot be generalized beyond the selected sample (Rao \& Tilt, 2016b). Given the context of this study, the REM is more appropriate.

$$
\begin{aligned}
& \text { QCSR }=\alpha+\beta_{1} A G E_{i t}+\beta_{2} \text { GENDER }_{i t}+\beta_{3} \text { NATION }_{i t}+ \\
& \beta_{4} \text { ETHNIC }_{i t}+\beta_{5} \text { EDULEVEL }_{i t}+\beta_{6} \text { EDUBGROUND }_{i t}+ \\
& \beta_{7} \text { TENURE }_{i t}+\beta_{8} \text { BODSIZE }_{i t}+\beta_{9} \text { BODMEET }_{i t}+ \\
& \beta_{10} \text { BODIND }_{i t}+\beta_{11} \text { ACSIZE }_{i t}+\beta_{12} \text { ACMEET }_{i t}+ \\
& \beta_{13} \text { ACIND }_{i t}+\beta_{14} \text { SIZE }_{i t}+\beta_{15} \text { LEV V }_{i t}+\beta_{16} \text { LOSSCO }_{i t}+ \\
& \beta_{17} \text { BIG }_{i t}+\beta_{18} \text { IEARDUMMY }_{i t}+\beta_{19} \text { INDUSTRYDUMMY }_{i t}+\varepsilon_{i t}
\end{aligned}
$$

where:

$\alpha=$ constant

$\beta=$ beta

$\varepsilon=$ error term

QCSR = quality of corporate social responsibility disclosure $\mathrm{AGE}=$ age diversity

GENDER = gender diversity

NATIONALITY = nationality diversity

ETHNICITY $=$ ethnic diversity

EDULEVEL = educational level diversity

EDUBGROUND = educational background diversity

TENURE $=$ tenure diversity

BODSIZE $=$ board size

BODMEET $=$ board meetings

BODIND $=$ board independence

ACSIZE $=$ audit committee size

ACMEET = audit committee meetings

ACIND $=$ audit committee independence

SIZE $=$ firm size

$\mathrm{LEV}=$ leverage ratio

LOSSCO $=$ firm's loss

BIG4 = audit quality

YEARDUMMY $=$ year effects

INDUSTRYDUMMY = industry effects 


\section{Results and Discussion}

\section{I Descriptive statistics}

Table 1 depicts the descriptive statistics. The mean of QCSR is 0.367 , ranging between 0.652 and 0.125 , which shows that firms in the financial sector of the PSX report very limited CSR information in their annual reports. The average value of age diversity is 0.383 , varying between 0.221 and 0.601 . The highest gender diversity in financial firms of the PSX is 0.201 , with a mean value of only 0.043 , which is similar to the value of 0.041 found by Barako and Brown (2008) for Kenyan banks. This indicates male-dominated boards and very low female representation on the boards of directors.

Gender diversity on the boards of the Pakistani financial sector reflects the global concerns about few women directors on firms' boards $s^{\text {vi }}$. The mean value of national diversity is 0.181 . Concerning ethnic diversity, the mean value is 0.641 . The results are consistent with Majeed (2010), who contends that Pakistan is a nation with a distinct ethnic diversity, defined in terms of the existence of four (i.e., Punjabi, Sindhi, Pashtuns, and
Balochi) ethnicities. Therefore, the financial firms' board members are highly ethnically diverse for commercial purposes to easily understand the requirements and preferences of stakeholders within each ethnic group.

Educational level diversity on the boards varies between 0.123 and 0.721 , with a mean value of 0.475 . This range reveals that there are firms with homogenous board educational level diversity, while some have a $72.1 \%$ heterogeneous educational levelvii. Similarly, 0.748 is the mean value of the educational background, which is lower than the mean value of 0.648 found by Hassan et al. (2020). For tenure diversity, the mean value is 0.577 , ranging from 0.000 to 0.804 , which indicates that there are firms with a homogeneous tenure, while some have an $80 \%$ heterogeneous tenure on their boards. The descriptive statistics for the control variables are shown in Table 1 . After splitting the sample data into banking and non-banking firms, we applied a paired sample t-test to examine if there was any difference between banking firms and non-banking firms in terms of the proposed relationship. Our findings show a higher presence of most of the variables in the banking firms; however, gender and tenure diversity have a high presence in the non-banking firms.

Table 1

\section{Descriptive statistics}

\begin{tabular}{|c|c|c|c|c|c|c|c|c|c|c|}
\hline \multirow[b]{2}{*}{ Variables } & \multirow[b]{2}{*}{ Obs. } & \multirow[b]{2}{*}{ Mean } & \multirow[b]{2}{*}{ SD } & \multirow[b]{2}{*}{ Min } & \multirow[b]{2}{*}{ Median } & \multirow[b]{2}{*}{ Max } & \multicolumn{4}{|c|}{ Paired Sample T-test } \\
\hline & & & & & & & $\begin{array}{c}\text { Banking } \\
\text { Firms' Mean }\end{array}$ & $\begin{array}{c}\text { Non- } \\
\text { Banking } \\
\text { Firms' Mean }\end{array}$ & MeanDiff. & T. Stat \\
\hline QCSR & 576 & 0.367 & 0.133 & 0.125 & 0.250 & 0.652 & 0.413 & 0.305 & 0.108 & $6.265^{* * *}$ \\
\hline AGE & 576 & 0.383 & 0.118 & 0.221 & 0.601 & 0.600 & 0.386 & 0.403 & -0.016 & -0.994 \\
\hline GENDER & 576 & 0.043 & 0.072 & 0.000 & 0.000 & 0.201 & 0.016 & 0.054 & -0.032 & $-3.759^{* * *}$ \\
\hline NATION & 576 & 0.181 & 0.201 & 0.000 & 0.200 & 0.700 & 0.179 & 0.181 & -0.180 & -0.064 \\
\hline ETHNIC & 576 & 0.641 & 0.082 & 0.400 & 0.700 & 0.800 & 0.673 & 0.663 & 0.010 & 0.857 \\
\hline EDULEVEL & 576 & 0.475 & 0.123 & 0.123 & 0.500 & 0.721 & 0.512 & 0.421 & 0.091 & $5.588^{* * *}$ \\
\hline EDUBGROUND & 576 & 0.748 & 0.573 & 0.560 & 0.700 & 0.800 & 0.342 & 0.234 & 0.108 & $4.453^{* * *}$ \\
\hline TENURE & 576 & 0.577 & 0.117 & 0.000 & 0.600 & 0.804 & 0.570 & 0.623 & -0.053 & $-3.293^{* * *}$ \\
\hline BODSIZE & 576 & 8.398 & 1.551 & 7.000 & 8.000 & 13.000 & 8.398 & 7.941 & 0.777 & $3.647^{* * *}$ \\
\hline BODMEET & 576 & 5.980 & 2.026 & 3.000 & 5.000 & 15.000 & 6.495 & 5.247 & 1.248 & $4.559^{* * *}$ \\
\hline BODIND & 576 & 0.196 & 0.156 & 0.020 & 0.140 & 0.570 & 0.247 & 0.123 & 0.123 & $6.050^{* * *}$ \\
\hline ACSIZE & 576 & 3.742 & 0.945 & 3.000 & 4.000 & 7.000 & 3.776 & 3.694 & 0.082 & 0.617 \\
\hline ACMEET & 576 & 4.956 & 2.135 & 4.000 & 5.000 & 23.000 & 5.305 & 4.458 & 0.846 & $3.851^{* * *}$ \\
\hline ACIND & 576 & 0.331 & 0.231 & 0.010 & 0.300 & 0.800 & 0.380 & 0.361 & 0.119 & $3.780^{* * *}$ \\
\hline SIZE (million \$) & 576 & 709.864 & 1145.6 & 4.849 & 328.86 & 9563.7 & 1031.19 & 179.683 & 851.511 & $3.962^{* * *}$ \\
\hline LEV & 576 & 0.556 & 0.886 & 0.001 & 5.800 & 4.200 & 0.788 & 0.244 & 0.543 & $4.536^{* * *}$ \\
\hline LOSSOCO & 576 & 0.131 & 0.338 & 0.000 & 0.100 & 1.000 & 0.123 & 0.141 & -0.017 & -0.358 \\
\hline BIG4 & 576 & 0.737 & 0.440 & 0.000 & 1.000 & 1.000 & 0.884 & 0.529 & 0.354 & $6.182^{* * *}$ \\
\hline
\end{tabular}

Note. Table 1 shows the sample statistics such as the number of observations, mean, median, maximum, minimum, standard deviation, and paired sample t-test for the banking and non-banking firms. 


\section{Correlation Matrix}

We applied a pairwise correlation to detect multicollinearity (Table 2). A coefficient of more than 0.80 to 0.90 shows that multicollinearity exists (Gujarati $\&$ Porter, 2009). Here, multicollinearity does not appear to be a serious issue for further analysis as the coefficient value of the variables falls below 0.80 .

\section{Panel Data Random Effects Regression Analyses}

The results documented in Table 3 are from first regressing the control variables against QCSR disclosure and then the board diversity variables along with the control variables, as shown in Models 1, 2, and 3. Model 2 is the baseline model and the other models are derived from it. In Model 1 we regress the control variables against QCSR disclosure. With regard to board characteristics, BODMEET ( $\beta=0.0490$, std. error $=0.0145)$ is positively significant for QCSR disclosure. The finding indicates that financial firms with more directors' meetings have a higher quality of QCSR disclosure. The result is consistent with those of Khan et al. (2010) for Bangladesh and Katmon et al. (2019) for Malaysia. However, BODSIZE has a nonsignificant relationship with QCSR disclosure, which is inconsistent with Nour et al. (2020), who found a positive relationship between board size and CSR practices. BODIND also has no impact on QCSR disclosure. This is consistent with the results of Yusof et al. (2019), who found no relationship between board independence and CSR disclosure.

In respect of audit committee characteristics, ACMEET $(\beta=0.0551$, std. error $=0.0206)$ has a positive impact on QCSR. The result shows that an increase in audit committee meetings improves the quality of CSR disclosure, as they can support and assist the firm's management in providing more quality information. However, ACSIZE and ACIND have no relationship with QCSR disclosure. With regard to firm-specific characteristics, SIZE $(\beta=0.0340$, std. error $=0.0107)$ is positively associated with QCSR disclosure, while LEV $(\beta=-0.0052$, std. error $=0.0021)$ is negatively associated with it. The result shows that large-sized firms' CSR disclosure is more qualitative, which means that firms with a higher market capitalization have more quality CSR disclosure practices as they have sufficient resources to invest in CSR activities. Our results for firm size and leverage are consistent with those of Giannarakis (2014). The R-squared of Model 1 is 0.5971 , which shows that the variables in Model 1 explain 59.71\% of QCSR disclosure.

As shown in Table 3, Model 2, we added board diversity variables to Model 1 and reran the regression. In Model 2, which is the baseline model, AGE ( $\beta=0.0919$, std. error $=0.0450)$ is significantly and positively associated with QCSR disclosure, demonstrating that age diversity is a valuable firm resource for improving QCSR disclosure. Age diversity improves firm innovativeness and creativeness, thereby improving the firm's competitive advantages and thus QCSR disclosure. Furthermore, age diversity, which has a negative relationship with CSR disclosure in the nonfinancial sector (Hassan et al., 2020; Khan et al., 2019b; Post, Rahman, \& Rubow, 2011), is positively significant in the financial sector. This is due to the differences between the financial sector and the non-financial sector (Katmon et al., 2019), characterized by the difference in institutional settings, with high regulatory intervention and tighter governance in the corporate environment of the former (Haniffa \& Cook, 2005; Said, Zainuddin, \& Haron, 2009). GENDER $(\beta=0.6010$, std. error $=0.1494)$ is found to have a highly significant and positive influence on QCSR disclosure. The results support the basic concepts of RBV theory, where gender diversity on a board improves corporate monitoring resources, which contribute to the improvement of quality decision making on CSR practices. Hence, our results support the enforcement of a female proportion on corporate boards in the financial sector of Pakistan and other developing countries.

The presence of EDULEVEL $(\beta=0.4495$, std. error $=0.2046)$ is found to be highly positively significant for QCSR, which demonstrates that board members with diverse educational levels may mitigate challenges in a sophisticated and strategic way. Alternative ideas are generated on strategic issues such as CSR disclosure when there is educational level diversity on a board, comparable to homogeneity in board educational level. The result for EDUBGROUND $(\beta=0.4401$, std. error $=0.2153)$ is significantly and positively associated with QCSR disclosure, indicating that a diverse educational background is a corporate resource, which contributes to competitive advantages and the quality of CSR disclosure. Firms that require board members from diverse educational backgrounds have vigorous debates on moral, ethical, legal, and financial issues, technical knowhow, and stakeholders' welfare before deciding on strategic issues. The result is consistent with that of Hassan et al. (2020), 


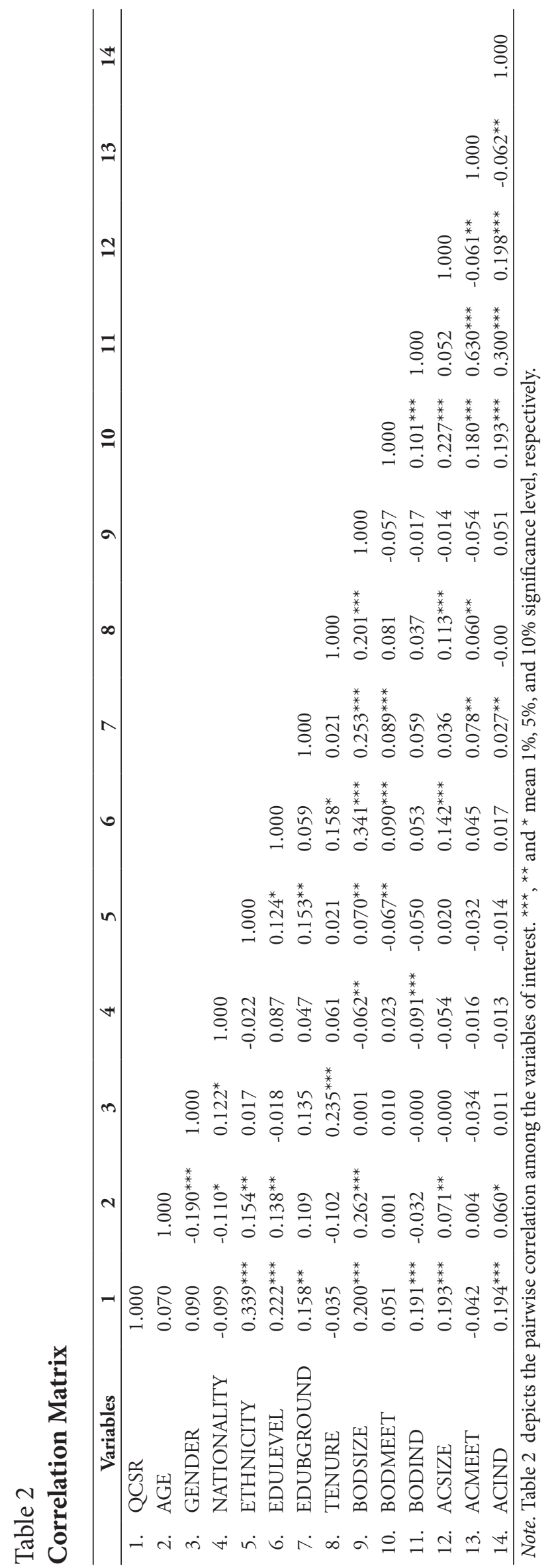


Table 3

Panel data random-effects regression for board diversity and QCSR disclosure

\begin{tabular}{|c|c|c|c|c|c|c|c|c|}
\hline & & Model 1 & Model 2 & Model 3 & Model 4 & Model 5 & Model 6 & Model 7 \\
\hline Variables & Exp. Sign & $\begin{array}{l}\text { Control } \\
\text { Variables }\end{array}$ & $\begin{array}{c}\text { Baseline } \\
\text { Model }\end{array}$ & $\begin{array}{c}\text { Robust } \\
\text { Regression }\end{array}$ & $\begin{array}{c}\text { QCSR } \\
\text { Alternative }\end{array}$ & $\begin{array}{c}\text { Diversity } \\
\text { Alternative }\end{array}$ & $\begin{array}{c}\text { AC Ch. } \\
\text { Alternative }\end{array}$ & $\begin{array}{l}\text { BOD Ch. } \\
\text { Alternative }\end{array}$ \\
\hline AGE & + & & $\begin{array}{l}0.0919^{* *} \\
(0.0450)\end{array}$ & $\begin{array}{c}0.0524 \\
(0.5155)\end{array}$ & $\begin{array}{c}0.2666^{*} \\
(0.1610)\end{array}$ & $\begin{array}{c}0.2939^{*} \\
(0.1687)\end{array}$ & $\begin{array}{l}0.5681^{* *} \\
(0.2438)\end{array}$ & $\begin{array}{c}0.5097 \\
(0.3543)\end{array}$ \\
\hline GENDER & + & & $\begin{array}{l}0.6010^{* * *} \\
(0.1494)\end{array}$ & $\begin{array}{l}0.0211^{* *} \\
(0.0108)\end{array}$ & $\begin{array}{c}6558^{* * *} \\
(0.2291)\end{array}$ & $\begin{array}{l}0.1541^{* * *} \\
(0.0422)\end{array}$ & $\begin{array}{l}0.9937^{* * *} \\
(0.3110)\end{array}$ & $\begin{array}{l}0.8207^{* * *} \\
(0.3684)\end{array}$ \\
\hline NATIONALITY & + & & $\begin{array}{l}-0.0419 \\
(0.0536)\end{array}$ & $\begin{array}{l}-0.0133 \\
(0.6787)\end{array}$ & $\begin{array}{l}-0.0441 \\
(0.0805)\end{array}$ & $\begin{array}{l}-0.0123 \\
(0.0348)\end{array}$ & $\begin{array}{l}-0.0155 \\
(0.1371)\end{array}$ & $\begin{array}{c}0.1528 \\
(0.1470)\end{array}$ \\
\hline ETHNICITY & + & & $\begin{array}{c}0.2037 \\
(0.1575)\end{array}$ & $\begin{array}{c}0.3290 \\
(0.2267)\end{array}$ & $\begin{array}{c}0.2953 \\
(0.2366)\end{array}$ & $\begin{array}{c}0.0539 \\
(0.1196)\end{array}$ & $\begin{array}{c}0.2972 \\
(0.4509)\end{array}$ & $\begin{array}{c}0.2811 \\
(0.5185)\end{array}$ \\
\hline EDULEVEL & + & & $\begin{array}{l}0.4495^{* * *} \\
(0.2046)\end{array}$ & $\begin{array}{c}0.0221^{*} \\
(0.0128)\end{array}$ & $\begin{array}{l}0.0822^{* *} \\
(0.0477)\end{array}$ & $\begin{array}{c}0.0502 \\
(0.0542)\end{array}$ & $\begin{array}{l}0.1318^{* * *} \\
(0.0411)\end{array}$ & $\begin{array}{l}0.0513^{* * *} \\
(0.0236)\end{array}$ \\
\hline EDUBGROUND & + & & $\begin{array}{l}0.4401^{* * *} \\
(0.2153)\end{array}$ & $\begin{array}{c}0.3674 \\
(0.2722)\end{array}$ & $\begin{array}{l}0.1352^{* *} \\
(0.0339)\end{array}$ & $\begin{array}{l}0.3939^{* * *} \\
(0.118)\end{array}$ & $\begin{array}{c}0.8353^{* *} \\
(0.4065)\end{array}$ & $\begin{array}{l}0.5576^{* * *} \\
(0.1641)\end{array}$ \\
\hline TENURE & + & & $\begin{array}{l}-0.1341 \\
(0.0972)\end{array}$ & $\begin{array}{c}0.0230 \\
(0.0369)\end{array}$ & $\begin{array}{l}-0.0135 \\
(0.1356)\end{array}$ & $\begin{array}{l}-0.0499 \\
(0.0779)\end{array}$ & $\begin{array}{l}-0.1749 \\
(0.1898)\end{array}$ & $\begin{array}{l}-0.01641 \\
(0.3003)\end{array}$ \\
\hline BODSIZE & + & $\begin{array}{l}-0.0716 \\
(0.0597)\end{array}$ & $\begin{array}{l}-0.0032 \\
(0.0081)\end{array}$ & $\begin{array}{l}-0.0035 \\
(0.7401)\end{array}$ & $\begin{array}{l}-0.0184 \\
(0.0121)\end{array}$ & $\begin{array}{l}-0.0130 \\
(0.0129)\end{array}$ & $\begin{array}{l}-0.0254 \\
(0.0183)\end{array}$ & $\begin{array}{l}-0.0569 \\
(0.0257)\end{array}$ \\
\hline BODMEET & + & $\begin{array}{l}0.0490^{* * *} \\
(0.0145)\end{array}$ & $\begin{array}{l}0.0204^{* * *} \\
(0.0062)\end{array}$ & $\begin{array}{c}0.0380 \\
(0.0216)\end{array}$ & $\begin{array}{l}0.0157^{* *} \\
(0.0056)\end{array}$ & $\begin{array}{l}0.0258^{* * *} \\
(0.0090)\end{array}$ & $\begin{array}{c}0.0297 \\
(0.0115)\end{array}$ & $\begin{array}{c}0.0601^{*} \\
(0.0324)\end{array}$ \\
\hline BODIND & + & $\begin{array}{l}-0.0460 \\
(0.0951)\end{array}$ & $\begin{array}{l}-0.1110 \\
(0.0931)\end{array}$ & $\begin{array}{l}-0.0349 \\
(0.0941)\end{array}$ & $\begin{array}{l}-0.1678 \\
(0.1309)\end{array}$ & $\begin{array}{l}-0.1599 \\
(0.1409)\end{array}$ & $\begin{array}{l}-0.2902^{* *} \\
(0.1521)\end{array}$ & $\begin{array}{l}-0.4337 \\
(0.6003)\end{array}$ \\
\hline ACSIZE & + & $\begin{array}{c}0.0398 \\
(0.0844)\end{array}$ & $\begin{array}{c}0.0126 \\
(0.0117)\end{array}$ & $\begin{array}{c}0.0337 \\
(0.0655)\end{array}$ & $\begin{array}{c}0.0130 \\
(0.0163)\end{array}$ & $\begin{array}{c}0.0134 \\
(0.0178)\end{array}$ & $\begin{array}{c}0.0165 \\
(0.0223)\end{array}$ & $\begin{array}{c}0.0622 \\
(0.0376)\end{array}$ \\
\hline ACMEET & + & $\begin{array}{l}0.0551^{* * *} \\
(0.0206)\end{array}$ & $\begin{array}{l}0.0138^{* * *} \\
(0.0045)\end{array}$ & $\begin{array}{c}0.0824 \\
(0.0973)\end{array}$ & $\begin{array}{l}0.0122^{* *} \\
(0.0064)\end{array}$ & $\begin{array}{l}0.0172^{* * *} \\
(0.0068)\end{array}$ & $\begin{array}{l}0.0169^{* * *} \\
(0.0065)\end{array}$ & $\begin{array}{l}0.0428^{* *} \\
(0.0198)\end{array}$ \\
\hline ACIND & + & $\begin{array}{c}0.0498 \\
(0.5831)\end{array}$ & $\begin{array}{c}0.0811 \\
(0.0609)\end{array}$ & $\begin{array}{c}0.0846 \\
(0.1746)\end{array}$ & $\begin{array}{c}0.2111^{*} \\
(0.1901)\end{array}$ & $\begin{array}{c}0.2159 \\
(0.7907)\end{array}$ & $\begin{array}{l}0.2752^{* * *} \\
(0.1023)\end{array}$ & $\begin{array}{c}0.0551 \\
(0.4147)\end{array}$ \\
\hline SIZE & + & $\begin{array}{l}0.0340^{* * *} \\
(0.0107)\end{array}$ & $\begin{array}{l}0.0397^{* * *} \\
(0.0094)\end{array}$ & $\begin{array}{l}0.0881^{* * *} \\
(0.0234)\end{array}$ & $\begin{array}{l}0.0397^{* * *} \\
(0.0094)\end{array}$ & $\begin{array}{l}0.0412^{* * *} \\
(0.0134)\end{array}$ & $\begin{array}{l}0.0732^{* * *} \\
(0.0264)\end{array}$ & $\begin{array}{c}0.638^{* *} \\
(0.0333)\end{array}$ \\
\hline LEV & + & $\begin{array}{l}-0.0052^{* * *} \\
(0.0021)\end{array}$ & $\begin{array}{l}0.0334^{* *} \\
(0.0146)\end{array}$ & $\begin{array}{l}-0.2159 \\
(0.7907)\end{array}$ & $\begin{array}{l}-0.0393^{* *} \\
(0.0131)\end{array}$ & $\begin{array}{l}0.0748^{* * *} \\
(0.0412)\end{array}$ & $\begin{array}{l}-0.0041 \\
(0.0297)\end{array}$ & $\begin{array}{l}0.1114^{* *} \\
(0.0561)\end{array}$ \\
\hline LOSSCO & + & $\begin{array}{l}-0.0449 \\
(0.2841)\end{array}$ & $\begin{array}{l}-0.0292 \\
(0.0445)\end{array}$ & $\begin{array}{c}0.0293 \\
(0.0231)\end{array}$ & $\begin{array}{l}-0.0698 \\
(0.0641)\end{array}$ & $\begin{array}{l}-0.0735 \\
(0.066)\end{array}$ & $\begin{array}{c}0.0152 \\
(0.0627)\end{array}$ & $\begin{array}{l}-0.1819 \\
(0.1167)\end{array}$ \\
\hline BIG4 & + & $\begin{array}{c}0.0476 \\
(0.1484)\end{array}$ & $\begin{array}{c}0.0264 \\
(0.0305)\end{array}$ & $\begin{array}{l}0.0548^{* *} \\
(0.0212)\end{array}$ & $\begin{array}{c}0.0005 \\
(0.0419)\end{array}$ & $\begin{array}{c}0.0205 \\
(0.0422)\end{array}$ & $\begin{array}{c}0.0172 \\
(0.0627)\end{array}$ & $\begin{array}{c}0.0852 \\
(0.0967)\end{array}$ \\
\hline _CONS & & $\begin{array}{l}0.4092^{* * *} \\
(0.0673)\end{array}$ & $\begin{array}{l}-0.2706 \\
(0.1847)\end{array}$ & $\begin{array}{l}-0.0693 \\
(0.1483)\end{array}$ & $\begin{array}{l}0.5308^{* * *} \\
(0.1902)\end{array}$ & $\begin{array}{l}-0.0241 \\
(0.2510)\end{array}$ & $\begin{array}{l}-0.4951 \\
(0.3291)\end{array}$ & $\begin{array}{c}0.0299 \\
(0.6917)\end{array}$ \\
\hline Year dummy & & Yes & Yes & Yes & Yes & Yes & Yes & Yes \\
\hline Industry dummy & & Yes & Yes & Yes & Yes & Yes & Yes & Yes \\
\hline Observations & & 576 & 576 & 576 & 576 & 576 & 576 & 576 \\
\hline Wald Chi' & & $97.655^{* * *}$ & $91.983^{* * *}$ & $76.901^{* * *}$ & $87.86^{* * *}$ & $56.83^{* * *}$ & $77.53^{* * *}$ & $37.70^{* * *}$ \\
\hline $\mathbf{R}^{2}$ & & 0.5971 & 0.5111 & 0.5111 & 0.5986 & 0.4716 & 0.4526 & 0.5315 \\
\hline
\end{tabular}

Note. Figure in the parentheses is the standard error, while the other figure shows the coefficient value. Bold values depict significant variables at ${ }^{* * *} \mathrm{p}<0.01,{ }^{* *} \mathrm{p}<0.05,{ }^{*} \mathrm{p}<0.1$

who found a significant and positive relationship between educational background diversity and CSR disclosure. Additionally, the results in Model 2 show that other diversity variables such as NATIONALITY, ETHNICITY, and
TENURE have no relationship with QCSR disclosure. Our findings for TENURE diversity are in line with those of Hassan et al. (2020) and Khan et al. (2019a), who found a non-significant impact of tenure on CSR 
disclosure. The results for ETHNICITY diversity are consistent with those of Katmon et al. (2019), who found no relationship between ethnic diversity and CSR disclosure for Malaysian listed firms.

For NATIONALITY diversity, our result is similar to in the previous study conducted by Barako and Brown (2008), who found no relationship between nationality diversity and CSR disclosure. Foreign directors in the financial sector of developing nations may not be able to carry out important CSR disclosure, because of the foreign directors' higher costs compared to local directors, ineffective monitoring, and unfamiliarity with local laws and regulations. The R-squared of Model 2 is 0.5111, which indicates that $51.11 \%$ of QCSR is explained by the variable in the model. The size of the R-squared conveys that the model is the one that best fits (Gujarati \& Porter, 2009). However, a low $R^{2}$ is the norm in various disclosure studies, such as that of Jizi (2017), who obtained an $\mathrm{R}^{2}$ ranging from $12 \%$ to $42 \%$ when examining the relationship between board composition and sustainable development disclosure. Muttakin et al. (2015) obtained an $\mathrm{R}^{2}$ ranging from $50 \%$ to $51.6 \%$ when investigating the impact of board characteristics on CSR disclosure. Rao and Tilt (2016) obtained an $\mathrm{R}^{2}$ from $41 \%$ to $67 \%$ when examining the relationship between board diversity and CSR reporting viii.

Again, to assess the robustness of the main results, we robustly analyzed Model 2, and reran the regression. The results remain consistent with the baseline model. Therefore, we can state that our results are robust in relation to other regression estimations. Furthermore, we used the alternative measurement for the dependent variable ${ }^{\mathrm{ix}}$, board diversity variables ${ }^{\mathrm{x}}$, board characteristics ${ }^{\mathrm{xi}}$, and audit committee characteristics ${ }^{\text {xii }}$ for a sensitivity analysis. The results of the REM are presented in Table 3, Models 4, 5,6 , and 7 . Despite noting some variation among the models, the results are almost consistent with the baseline findings. Thus, we contend that our results remain robust and unchanged across alternative measurement procedures.

\section{Generalized Method of Moments (GMM) Regression}

Previous literature has shown that board diversity is subject to endogeneity issues (Chang et al., 2017; Harjoto et al., 2015; Upadhyay \& Zeng 2014). Endogeneity refers to a situation in which the independent variables are correlated with the error term (Gujarati \& Porter, 2009). It occurs when the dependent variables and independent variables simultaneously cause each other and the casual effects are reciprocal (Wooldridge, 2002). Moreover, it occurs due to omitted variables or simultaneity in the proposed model (Katmon et al., 2019). This reverse causality/endogeneity may result in inconsistent and biased coefficients of the estimated model (Akbar, Poletti-Hughes, El-Faitouri, \& Shah, 2016; Roberts \& Whited, 2011).

There is extensive literature on the application of semiparametric models (Atak, Linton, \& Xiao, 2011; Chen et al., 2012; Connor, Hagmann, \& Linton, 2012) to overcome endogeneity issues in empirical studies with heterogeneous panel data (Chen et al., 2012). For this purpose, a dynamic panel estimator developed by Arellano and Bond (1991) based on GMM is generally used to tackle reverse causality or endogeneity issues. GMM estimation is widely used as it outperforms all the other estimators in terms of bias and efficiency (Soto, 2009). Blundell and Bond (1998) also showed the superiority of GMM over other estimators. Therefore, we applied system GMM to overcome the limitations identified in earlier empirical studies and support our GLS calculations. Previous studies on corporate governance and CSR practices have also used GMM (Chang et al., 2017; Hunjra et al., 2020; Khan et al., 2019a).

The main weakness of system GMM is that it requires a large number of instrumental variables (Roodman, 2009b). GMM instruments may not perform effectively when the regressor variables are persistent over time (Blundell $\&$ Bond, 1998). To fix this issue, Roodman (2009a) executed the xtabond2 package in STATA software. The second weakness with GMM is the potential problem of over-identification if the instruments are too large. The Hansen and differencein-Hansen tests provide weak results in the presence of over-identification (Roodman, 2009b). Increasing with the time dimension, the number of instruments may be too large compared to the sample size, undermining some asymptotic results. Different statistical and post-diagnostic tests are performed to examine the validity and strength of the model as well as the instrumental variables. For each model we documented the estimated coefficient, Hansen test of validity ${ }^{\text {xiii }}, 1$ st order test (AR 1), 2nd order $(A R 2)^{x i v}$, and F-test ${ }^{\mathrm{xv}}$. The diagnostic test's significant as well as non-significant values determine the validity of the different instruments and robustness of the results. Based on the post-diagnostic tests, we can conclude that the estimated models and instruments are adequately specified.

Table 4, Models 1, 2, 3, 4, and 5 present the GMM results. As documented in Table 4, Model 1, 
Table 4

GMM Regression Analysis

\begin{tabular}{|c|c|c|c|c|c|c|}
\hline \multirow{3}{*}{ Variables } & \multirow{3}{*}{$\begin{array}{l}\text { Exp. } \\
\text { signs }\end{array}$} & Model 1 & Model 2 & Model 3 & Model 4 & Model 5 \\
\hline & & QCSR & QCSR & Diversity & Board Ch. & AC Ch. \\
\hline & & Baseline & Alternative & Alternative & Alternative & Alternative \\
\hline \multirow[t]{2}{*}{ AGE } & + & $0.4294^{* * *}$ & $0.5690^{* *}$ & 0.3939* & 0.2217 & $0.1310^{* *}$ \\
\hline & & $(0.1959)$ & $(0.3791)$ & $(0.1597)$ & $(0.3175)$ & $(0.0246)$ \\
\hline \multirow[t]{2}{*}{ GENDER } & + & $0.3313^{*}$ & $0.4547^{* *}$ & $0.2531^{* * *}$ & $0.2601^{* * *}$ & $0.0991^{* *}$ \\
\hline & & $(0.1785)$ & $(0.2134)$ & $(0.0372)$ & $(0.0144)$ & $(0.0549)$ \\
\hline \multirow[t]{2}{*}{ NATIONALITY } & + & -0.1673 & -0.7866 & 0.5639 & -0.8531 & 0.0529 \\
\hline & & $(0.5288)$ & $(0.7145)$ & $(0.3618)$ & $(0.7469)$ & $(0.0695)$ \\
\hline \multirow[t]{2}{*}{ ETHNICITY } & + & 0.3722 & 0.7527 & $0.4539^{* *}$ & 0.1355 & -0.4017 \\
\hline & & $(0.3289)$ & $(0.4294)$ & $(0.1196)$ & $(0.6397)$ & $(0.4074)$ \\
\hline \multirow[t]{2}{*}{ EDULEVEL } & + & $0.9458^{* * *}$ & $0.335^{* * *}$ & -0.0123 & $0.1922^{* * *}$ & $0.0541^{*}$ \\
\hline & & $(0.2667)$ & $(0.089)$ & $(0.0348)$ & $(0.0535)$ & $(0.0291)$ \\
\hline \multirow[t]{2}{*}{ EDUBGROUND } & + & $0.6744^{* * *}$ & $0.5166^{* * *}$ & $0.3939^{* *}$ & $0.5331^{* *}$ & 0.7029 \\
\hline & & $(0.2818)$ & $(0.2450)$ & $(0.1118)$ & $(0.2769)$ & $(0.6095)$ \\
\hline \multirow[t]{2}{*}{ TENURE } & + & 0.0240 & -0.8269 & -0.0467 & -0.0554 & -0.0603 \\
\hline & & $(0.2639)$ & $(0.3703)$ & $(0.0679)$ & $(0.2825)$ & $(0.0482)$ \\
\hline \multirow[t]{2}{*}{ BODSIZE } & + & 0.0617 & $0.0665^{* *}$ & -0.0139 & -0.1352 & $-0.0874^{*}$ \\
\hline & & $(0.0532)$ & $(0.0327)$ & $(0.0149)$ & $(0.1772)$ & $(0.0515)$ \\
\hline \multirow[t]{2}{*}{ BODMEET } & + & 0.0340 & 0.0153 & $0.0348^{* * *}$ & $0.1302^{*}$ & -0.0344 \\
\hline & & $(0.0187)$ & $(0.0114)$ & $(0.0081)$ & $(0.0501)$ & $(0.0310)$ \\
\hline \multirow[t]{2}{*}{ BODIND } & + & $0.5417^{*}$ & $0.3291^{* *}$ & -0.1599 & $0.4224^{* * *}$ & $0.0991^{* *}$ \\
\hline & & $(0.0315)$ & $(0.1217)$ & $(0.1409)$ & $(0.1176)$ & $(0.0356)$ \\
\hline \multirow[t]{2}{*}{ ACSIZE } & + & 0.0345 & -0.0142 & 0.0413 & $0.0336^{* * *}$ & 0.0162 \\
\hline & & $(0.0441)$ & $(0.0512)$ & $(0.0178)$ & $(0.0136)$ & $(0.0913)$ \\
\hline \multirow[t]{2}{*}{ ACMEET } & + & $0.0412^{* *}$ & $0.0527^{* * *}$ & $0.0172^{* * *}$ & $0.0113^{* *}$ & -0.0431 \\
\hline & & $(0.0211)$ & $(0.0311)$ & $(0.0056)$ & $(0.0065)$ & $(0.0511)$ \\
\hline \multirow[t]{2}{*}{ ACIND } & + & 0.0119 & 0.0156 & -0.0348 & -0.2533 & 0.2533 \\
\hline & & $(0.1710)$ & $(0.0728)$ & $(0.0312)$ & $(0.2075)$ & $(0.2075)$ \\
\hline \multirow[t]{2}{*}{ SIZE } & + & $0.2141^{* * *}$ & $0.1511^{* * *}$ & $0.04712^{* * *}$ & $0.2941^{* * *}$ & $0.0247^{* * *}$ \\
\hline & & $(0.0661)$ & $(0.0415)$ & $(0.0114)$ & $(0.1401)$ & $(0.0085)$ \\
\hline \multirow[t]{2}{*}{ LEV } & + & $-0.2759^{* *}$ & $-0.3769^{*}$ & $-0.2149^{* * *}$ & -0.2280 & $-0.0244^{* *}$ \\
\hline & & $(0.1211)$ & $(0.2301)$ & $(0.0107)$ & $(0.0750)$ & $(0.0022)$ \\
\hline \multirow[t]{2}{*}{ LOSSCO } & + & -0.0018 & -0.0155 & -0.0734 & -0.0140 & $-0.0331^{*}$ \\
\hline & & $(0.0205)$ & $(0.0251)$ & $(0.0616)$ & $(0.0188)$ & $(0.0116)$ \\
\hline \multirow[t]{2}{*}{ BIG4 } & + & 0.1319 & 0.1782 & $0.3454^{* *}$ & 0.0131 & 0.0225 \\
\hline & & $(0.0512)$ & $(0.6514)$ & $(0.1415)$ & $(0.0459)$ & $(0.0622)$ \\
\hline \multirow[t]{2}{*}{ _CONS } & & -0.4854 & 0.0913 & -0.0541 & 0.4316 & 0.8619 \\
\hline & & $(0.5548)$ & $(0.7027)$ & $(0.2510)$ & $(0.7722)$ & $(0.7512)$ \\
\hline \multicolumn{2}{|l|}{ Year dummy } & Yes & Yes & Yes & Yes & Yes \\
\hline \multicolumn{2}{|l|}{ Industry dummy } & Yes & Yes & Yes & Yes & Yes \\
\hline Observations & & 576 & 576 & 576 & 576 & 576 \\
\hline$F$ test & & 11.311 & 14.232 & 9.385 & 11.493 & 8.443 \\
\hline Prob. $>$ F & & 0.0000 & 0.0000 & 0.0000 & 0.0000 & 0.0000 \\
\hline Hansen test & & 0.5662 & 0.3968 & 0.8451 & 0.3265 & 0.7538 \\
\hline $\operatorname{AR}(1)$ & & $0.0366^{* * *}$ & $0.0731^{* *}$ & $0.0821^{* *}$ & $0.0884^{* * *}$ & $0.0752^{* * *}$ \\
\hline $\operatorname{AR}(2)$ & & 0.7970 & 0.5319 & 0.0683 & 0.5334 & 0.7458 \\
\hline
\end{tabular}

Note. The figure in the parentheses is the standard error, while the other figure is the coefficient of the variables. Bold values depict significant variables at ${ }^{* *} \mathrm{p}<0.01,{ }^{* *} \mathrm{p}<0.05,{ }^{*} \mathrm{p}<0.1$. 
AGE $(\beta=0.4294$, std. error $=0.1959)$, GENDER $(\beta=0.3313$, std. error $=0.1785)$, EDULEVEL $(\beta=0.9458$, std. error $=0.2667)$, and EDUBGROUND $(\beta=0.6744$, std. error $=0.2818)$ are positively related to QCSR disclosure in the financial sector of Pakistan. These findings are similar to our baseline results tabulated in Table 3, Model 2, and Model 3 validates our baseline estimations. We applied a similar regression (i.e. GMM) with regard to the other models in Table 3 (i.e. Models 4, 5, 6, and 7) and present the results in Table 4, Models 2, 3, 4, and 5. We found that the results of Table 4 along with the other variables are mostly similar to the results we presented in Table 3. Therefore, we conclude that our GLS results are robust to the endogeneity issue because our GMM estimation provides consistent results.

\section{I0 Conclusion}

Firms' involvement in CSR disclosure and sustained competitive advantages suggest that board characteristics, specifically board diversity, should have a relationship with CSR practices. Despite the increasing literature on corporate governance and CSR in developing nations (Al-Fadli et al., 2019; Ajaz et al., 2020; Hassan et al., 2020; Olthuis \& Oever, 2020; Wellalage et al., 2018), the relationship between board diversity and the quality of CSR disclosure in the financial sector has been relatively under investigated. Therefore, we examined the influence of board diversity on CSR disclosure and predicted that the relationship may be patterned differently from in prior literature in different contexts and nations, due to their distinctive characteristics. The analysis is conducted for 64 financial firms over nine (9) years from 2010 to 2018, using multiple regressions, and the results are presented from the perspective of the resource-based view (RBV) theory.

The results from the random-effects GLS regression and generalized method of moments (GMM) demonstrate that board age, gender, educational level, and educational background diversities are significantly and positively associated with the quality of QCSR disclosure. Our findings support the basic concepts of RBV theory in the sense that age, gender, educational level, and educational background diversities are firm resources that are valuable, rare, inimitable, and non-substitutable, and drive the firms towards the achievement of competitive advantages through CSR practices. Concerning gender diversity, our results also provide a supportive argument for at least one female directorship quota in Pakistani firms as mandatory from 2017 in the new 2017 Corporate Governance Code of Pakistan (Securities and Exchange Commission of Pakistan, 2017). The growing interest in studying gender diversity is due to the pressure from regulatory entities (Goncalves, Gaio, \& Santos, 2019). Furthermore, not all the diversity variables are significantly associated with QCSR disclosure, such as nationality, ethnic, and tenure diversities, which are not significantly associated with QCSR disclosure.

Unlike other research findings, our study fills the gap in the preceding literature by providing preliminary arguments on the influence of board diversity on CSR disclosure in the financial sector of developing nations. We react to the comments made by Ibrahim and Hanefah (2016) and Hoang et al. (2018) that studies on comprehensive board diversity variables and their relationship with CSR disclosure are limited in developing nations. We also respond to the comments made by Rao and Tilt (2016a) that studies on educational level, educational background, and ethnic diversities are very limited. Most notably, the existing studies mostly focus on resource dependency theory, agency theory, stakeholder theory, and legitimacy theory, etc. (Abdullah \& Ismail, 2013; Chang et al., 2017; Harjoto et al., 2019; Hassan et al., 2020), and none of these studies have provided evidence based on the resource-based view (RBV) theory. We make a contribution to the theoretical literature by examining board diversity and CSR relationships in developing economies from the perspective of RBV theory.

This research has a number of beneficial implications. The results of the study could be a valuable source of knowledge for regulators and policy-makers, mostly for the financial sector in developing nations. We recommend that firms in the financial sector plan to diversify their board structure according to age, gender, educational level, and educational background to improve their competitive advantages. In line with RBV theory, these resources play a major role in strategic decisions on CSR practices, which may be superior to other competitors in this arena. The new CG code of 2017 in Pakistan calls for at least one female on the board. Inconsistently with Khan et al. (2019b), we recommend policymakers and the regulatory authority encourage a mandatory percentage of female directors globally, such as in Norway, Spain, and France, where the percentage of female directors is 40\% (Galia \& Zenou, 2013; Upadhyay \& Zeng, 2014), 
while in Malaysia the percentage for female directorship is $30 \%$ (Abdullah \& Ismail, 2013) and one third in Italy (Giovinco, 2014).

The study has some limitations. First, the sample of 64 financial firms is considered relatively small, although it is among the largest samples in the research of board diversity and CSR disclosure in the financial sector. Second, other diversity variables such as experience, directorship quality, culture, religion, and expertise are considered important, but these are too problematic to measure and analyze, which is an unavoidable limitation. Regardless of the above limitations, we are confident that the present study is relevant and timely and contributes to the relevant literature on emerging economies, specifically Pakistan.

Future studies could investigate the influence of interaction variables constructed based on diversity variables that are significant to CSR disclosure. We further contend that the impact of board diversity on CSR disclosure may differ in other emerging market countries. Therefore, research studies in a similar context may offer different results in different developing nations compared to the results provided by the current study.

\section{Notes}

i We argue that CSR disclosure and CSR performance are two different concepts. CSR performance is the configuration of principles of social responsibility, social responsiveness, and policies, programs, and observable outcomes associated with the firm's social relationships (Wood, 1991).

ii Tangible assets include financial assets (reported in the balance sheet) (Grant, 1991), and intangible assets comprise different possibilities such as skills, knowledge, experience (Helfat \& Peteraf, 2003), national and international heterogeneity, and gender diversity.

iii Pakistan Institute of Corporate Governance, Institute of Corporate and Management Accountants of Pakistan, CSR Center of Pakistan, Institute of Chartered Accountants of Pakistan, and International Integrated Reporting Council.

iv $\quad B I=1-\sum_{i=1}^{n} P_{i}^{2}$ where $\mathrm{BI}$ is the Blau's index, “i” represents many categories, " $n$ " represents the members in each category, and " $\mathrm{t}$ " represents the proportion of board members in each category, respectively. The Blau's index takes values between zero and one. " 0 " shows no heterogeneity while " 1 " shows complete heterogeneity.

$v$ The age of board members in Pakistani financial firms is mostly near to or more than 40 years old. Therefore, we selected the smallest categories of 40 years old accordingly.

vi For example, a study conducted by Garcia-Meca et al. (2018) demonstrates that financial firms in Canada, France, Germany, Italy, Netherlands, Spain, Sweden, the UK, and the USA have an average of 0.092 female representation on their boards.

vii We note that numerous business tycoons such as Bill Gates, Steve Jobs, and Mark Zuckerberg are extremely successful individuals who did not even complete their college degrees.

viii For further information, see Kolk and Pinkse (2010), Saleh et al. (2010), Michelon and Parbonetti (2012), Platonova et al. (2018), Harjoto et al. (2019), and Katmon et al. (2019). These studies find an $\mathrm{R}^{2}$ ranging from $30 \%$ to $60 \%$ when investigating CSR performance/disclosure in various contexts.

ix CSR disclosure is a dummy measurement and the ratio of the firm's total score divided by the items in the index (Saleh et al., 2010).

$x$ AGE is the standard deviation of the directors' age (Katmon et al., 2019). For GENDER, the firms with at least one female director are given the value " 1 " and "0" otherwise. For NATIONALITY, the boards with at least one foreign nationality are given the value " 1 " and " 0 " otherwise. ETHNICITY is the ratio of directors' ethnicity to the total members on a board, excluding the majority members' ethnic group. EDULEVEL is the proportion of directors with other educational qualifications. EDUBGROUND is the proportion of board members with more than one educational background compared to the total members on the board. TENURE is measured using the proportion of members with fewer than 3 years of tenure compared to the total board members.

xi An alternative measurement for board characteristics is based on median values, using dummies such as BODSIZE, which is measured using " 1 " for firms with a large board size, and "0" for a small board 
size. BODMEET is measured using " 1 " for a high frequency, and " 0 " for a low frequency of board meetings. BODIND is measured using "1" for high and " 0 " for low director independence.

xii Alternative measurements for audit committee characteristics are based on median values, using dummies such as ACSIZE, which is measured using " 1 " for firms with a large audit committee size, and " 0 " for a small-sized audit committee. ACMEET is measured using " 1 " for a high frequency, and " 0 " for a low frequency of audit committee meetings. ACIND is measured using " 1 " for high and " 0 " for low audit committee independence in a specific year.

xiii Baum et al. (2003) assert that a non-significant Hansentest value ensures the validity of over-identification restrictions, suggesting the validity of the instrumental variables.

xiv According to Roodman (2009b), a significant value for AR (1) and a non-significant value for AR (2) show that the first order (AR1) correlation matters and at the second stage (AR2) the correlation is absent.

xv In line with Khan et al. (2019b), the F-test indicates that the selected instrumental variables are strong and valid at $\mathrm{p}<0.0000$

\section{References}

Abdelbadie, R. A., \& Salama, A. (2019). Corporate governance and financial stability in US banks: Do indirect interlocks matter? Journal of Business Research, 104, 85-105.

Abdullah, S. H., \& Raman, S. (2001). Quantitative and qualitative research methods: Some strengths and weaknesses. Jurnal Pendidik dan Pendidikan, 17(1), 120-134.

Abdullah, S. N., \& Ismail, K. N. I. K. (2013). Gender, ethnic, and age diversity of the boards of large Malaysian firms and performance. Jurnal Pengurusan, 38, 27-40.

Adams, R. B., \& Ferreira, D. (2009). Women in the boardroom and their impact on governance and performance. Journal of Financial Economics, 94(2), 291-309.

Ahmed, F. (1996). Pakistan: Ethnic fragmentation or national integration? The Pakistan Development Review, 35(4), 631-645.
Ajaz, A., Shenbei, Z., \& Sarfraz, M. (2020). Delineating the influence of boardroom gender diversity on corporate social responsibility, financial performance, and reputation. Log forum, 16(1), 61-74.

Akbar, S., Poletti-Hughes, J., El-Faitouri, R., \& Shah, S. Z. A. (2016). More on the relationship between corporate governance and firm performance in the UK: Evidence from the application of generalized method of moment's estimation. Research in International Business and Finance, 38, 417-429.

Aldaas, A. A., Mohammad, S. J., \& Abuhashesh, M. Y. (2019). Successful implementation of corporate governance mechanisms in banks. Journal of Social, 8(4), 692-710.

Al-Fadli, A., Sands, J., Jones, G., Beattie, C., \& Pensiero, D. (2019). Board gender diversity and CSR reporting: Evidence from Jordan. Australasian Accounting, Business and Finance Journal, 13(3), 29-52.

Al-Rahahleh, A. S. (2017). Corporate governance quality, board gender diversity and corporate dividend policy: Evidence from Jordan. Australasian Accounting, Business and Finance Journal, 11(2), 86-104.

Al-Tuwaijri, S. A., Christensen, T. E., \& Hughes, K. E. (2004). The relations among environmental disclosure, environmental performance, and economic performance: A simultaneous equations approach. Accounting, Organizations and Society, 29(5-6), 447-471.

Arellano, M., \& Bond, S. (1991). Some tests of specification for panel data: Monte Carlo evidence and an application to employment equations. Review of Economic Standard, 58(2), 277-297.

Atak, A., Linton, O., \& Xiao, Z. (2011). A semiparametric panel model for unbalanced data with application to climate change in the United Kingdom. Journal of Econometrics, 164(1), 92-115.

Axjonow, A., Ernstberger, J., \& Pott, C. (2018). The impact of corporate social responsibility disclosure on corporate reputation: A non-professional stakeholder perspective. Journal of Business Ethics, 151(2), 429-450.

Ayuso, S., \& Argandona, A. (2009). Responsible corporate governance: Towards a stakeholder board of directors? 
(NBER Working Paper No. 701). Retrieved from https:// media.iese.edu/research/pdfs/DI-0701-E.pdf

Azim, M. T. (2016). Corporate social responsibility and employee behavior: Mediating role of organizational commitment. Review of Business Management, 18(60), 207-225.

Baltagi, B. H. (2005). Econometric analysis of panel data. West Sussex: John Wiley and Sons.

Baraibar-Diez, E., \& Sotorrío, L. L. (2018). The mediating effect of transparency in the relationship between corporate social responsibility and corporate reputation. Review of Business Management, 20(1), 5-21.

Barako, D. G., \& Brown, A. M. (2008). Corporate social reporting and board representation: Evidence from the Kenyan banking sector. Journal of Management and Governance, 12(4), 309-324.

Barney, J. (1991). Firm resources and sustained competitive advantage. Journal of Management, 17(1), 99-120.

Barney J.B., \& Clark D.N. (2007). Resource-based theory: Creating and sustaining a competitive advantage. New York: Oxford University Press.

Barroso, C., Villegas, M. M., \& Perez-Calero, L. (2011). Board influence on a firm's internationalization. Corporate Governance: An International Review, 19(4), 351-367.

Baum, C. F., Schaffer, M. E., \& Stillman, S. (2003). Instrumental variables and GMM: Estimation and testing. Stata Journal, 3(1), 1-31.

Bhatti, F. A., Uddin, M., Ahmed, A., \& Bugert, P. (2010). Human platelet antigen polymorphisms (HPA囚1, 囚2, $\bigotimes 3, \nabla 4, \bigotimes 5$ and $\nabla 15$ ) in major ethnic groups of Pakistan. Transfusion Medicine, 20(2), 78-87.

Blau, P. M. (1977). Inequality and Heterogeneity. New York: The Free Press.

Blundell, R., \& Bond, S. (1998). Initial conditions and moment restrictions in dynamic panel data models. Journal of Econometrics, 87(1), 115-143.

Bonson, E., \& Bednarova', M. (2014). CSR reporting practices of Eurozone companies. Spanish Accounting Review, 38, 1-12.
Cacioppo, J. T., Semin, G. R., \& Berntson, G. G. (2004). Realism, instrumentalism, and scientific symbiosis: Psychological theory as a search for truth and the discovery of solutions. American Psychologist, 59(4), 214-223.

Carter, D., D’Souza, F., Simkins, B. J., \& Simpson, W. G. (2010). The gender and ethnic diversity of US boards and board committees and firm financial performance. Corporate Governance: An International Review, 18(5), 396-414.

Cohen, L., \& Manion, L. (1994). Research methods in education (4th ed.). London: Routledge.

Connor, G., Hagmann, M., \& Linton, O. (2012). Efficient semiparametric estimation of the Fama-French model and extensions. Econometrica, 80(2), 713-754.

Chang, Y. K., Oh, W. Y., Park, J. H., \& Jang, M. G. (2017). Exploring the relationship between board characteristics and CSR: Empirical evidence from Korea. Journal of Business Ethics, 140(2), 225-242.

Chen, J., Gao, J., \& Li, D. (2012). Semiparametric trending panel data models with cross-sectional dependence. Journal of Econometrics, 171(1), 71-85.

Chuang, S. P., \& Huang, S. J. (2016). The effect of environmental corporate social responsibility on environmental performance and business competitiveness: The mediation of green information technology capital. Journal of Business Ethics, 150(4), 991-1009.

El-Bassiouny, D., \& El-Bassiouny, N. (2019). Diversity, corporate governance, and CSR reporting. Management of Environmental Quality, 30(1), 116-136.

Elias, A. A., Cavana, R. Y., \& Jackson, L. S. (2002). Stakeholder analysis for $\mathrm{R} \& \mathrm{D}$ project management. $R \& D$ Management, 32(4), 301-310.

Elias, A. A. (2012). A system dynamics model for stakeholder analysis in environmental conflicts. Journal of Environmental Planning and Management, 55(3), 387-406.

Elias, A. A. (2019). Strategy development through stakeholder involvement: A New Zealand study. Global Journal of Flexible Systems Management, 20(4), 313-322. 
Elias, A. A., \& Davis, D. (2018). Analyzing public sector continuous improvement: A systems approach. International Journal of Public Sector Management, 31(1), 2-13.

Elias, A. A., \& Mathew, S. K. (2015). Offshore IT outsourcing between India and New Zealand: A systemic analysis. Pacific Asia Journal of the Association for Information Systems, 7(3), 33-54.

Elyasiani, E., \& Zhang, L. (2015). Bank holding company performance, risk, and "busy" board of directors. Journal of Banking \& Finance, 60, 239-251.

Fisman, Ray, Geoffrey Heal, and Vinay B. Nair. 2007. VA Model of Corporate Philanthropy. V Working Paper. Columbia University.

Frączkiewicz-Wronka, A., \& Szymaniec, K. (2012). Resource-based view and resource dependence theory in decision-making process of public organization-research findings. Management, 16(2), 16-29.

Freeman, R. E. (1984). Strategic management: A stakeholder approach. Boston: Pitman.

Freeman, R. E., Harrison, J. S., \& Zyglidopoulos, S. (2018). Stakeholder theory: Concepts and strategies. Cambridge: Cambridge University Press.

Freeman, R. E., Wicks, A. C., \& Parmar, B. (2004). Stakeholder theory and "the corporate objective revisited". Organization Science, 15(3), 364-369.

Frynas, J. G., \& Yamahaki, C. (2016). Corporate social responsibility: Review and roadmap of theoretical perspectives. Business Ethics: A European Review, 25(3), 258-285.

Galbreath, J. (2005). Which resources matter the most to firm success? An exploratory study of resource-based theory. Technovation, 25(9), 979-987.

Galbreath, J. (2016). When do board and management resources complement each other? A study of effects on corporate social responsibility. Journal of Business Ethics, 136(2), 281-292.

Galia, F., \& Zenou, E. (2013). Does board diversity influence innovation? The impact of gender and age diversity on innovation types. Conference International de Management Strategic, Paris, France, 22.Retrivied from https://www. strategie-aims.com/events/conferences/23-xxiieme-conferencede-l-aims/communications/2959-does-board-diversityinfluence-innovation-the-impact-of-gender-and-agediversity-on-innovation-types/download\#: - :text=Our\%20 results $\% 20$ show $\% 20$ evidence $\% 20$ of,of $\% 20$ innovation $\% 20$ except $\% 20$ process $\% 20$ innovation. \&text=Age $\% 20$ diversity $\% 20$ shows $\% 20$ a $\% 20$ positive,of $\% 20$ board $\% 20$ diversity\%20on\%20innovation.

Gangi, F., Meles, A., D’Angelo, E., \& Daniele, L. M. (2019). Sustainable development and corporate governance in the financial system: Are environmentally friendly banks less risky? Corporate Social Responsibility and Environmental Management, 26(3), 529-547.

Garcia-Meca, E., Uribe-Bohorquez, M.V., \& CuadradoBallesteros (2018). Culture, board composition and corporate social reporting in the banking sector. Administrative Sciences, 8(3), 44-56.

Giannarakis, G. (2014). Corporate governance and financial characteristic effects on the extent of corporate social responsibility disclosure. Social Responsibility Journal, 10(4), 569-590.

Gill, A. (2008). Corporate governance as social responsibility: A research agenda. Berkeley Journal of International Law, 26(2), 452-477.

Giovinco, A. (2014). Gender diversity in the boardroom: Context and Spanish case. Corporate Board: Role, Duties \& Composition, 10(3), 60-76.

Goncalves, T., Gaio, C., \& Santos, T. (2019). Women on the board: Do they manage earnings? Empirical evidence from European listed firms. Review of Business Management, 21(3), 582-597.

Grant, R. M. (1991). The resource-based theory of competitive advantage: Implications for strategy formulation. California Management Review, 33(3), 114-135.

Gujarati, D. N., \& Porter, D. C. (2009). Basic Econometrics, Fifth Edition. New York: McGraw Hill.

Hafsi, T., \& Turgut, G. (2013). Boardroom diversity and its effect on social performance: Conceptualization and empirical evidence. Journal of Business Ethics, 112(3), 463-479 
Hamel, G., \& Praharad, C. K. (1994). Competing for the future. Boston: Harvard, Business School Press.

Haniffa, R. M., \& Cooke, T. E. (2005). The impact of culture and governance on corporate social reporting. Journal of Accounting and Public Policy, 24(5), 391-430.

Harjoto, M., Laksmana, I., \& Lee, R. (2015). Board diversity and corporate social responsibility. Journal of Business Ethics, 132(4), 641-660.

Harjoto, M. A., Laksmana, I., \& Yang, Y. W. (2019). Board nationality and educational background diversity and corporate social performance. Corporate Governance: The International Journal of Business in Society, 19(2), 217-238.

Hassan, L. S., Saleh, N. M., \& Ibrahim, I. (2020). Board diversity, company's financial performance and corporate social responsibility information disclosure in Malaysia. International Business Education Journal, 13(1), 23-49

Helfat, C. E., \& Peteraf, M. A. (2003). The dynamic resource-based view: Capability lifecycles. Strategic Management Journal, 24(1), 997-1010.

Henning, E., Rensburg, W. van, \& Smit, B. (2004). Finding your way in qualitative research. New York: Van Schaik Publishers.

Hoang, T. C., Abeysekera, I., \& Ma, S. (2018). Board diversity and corporate social disclosure: Evidence from Vietnam. Journal of Business Ethics, 151(3), 833-852.

Hunjra, A. I., Mehmood, R., \& Tayachi, T. (2020). How do corporate social responsibility and corporate governance affect stock price crash risk? Journal of Risk and Financial Management, 13(2), 1-15.

Ibrahim, A. H., \& Hanefah, M. M. (2016). Board diversity and corporate social responsibility in Jordan. Journal of Financial Reporting and Accounting, 14(2), 279-298.

Jafar, T. H., Levey, A. S., Jafary, F. H., White, F., Gul, A., Rahbar, M. H., ... Chaturvedi, N. (2003). Ethnic subgroup differences in hypertension in Pakistan. Journal of hypertension, 21(5), 905-912.

Jizi, M. (2017). The influence of board composition on sustainable development disclosure. Business Strategy and Environment, 26(5), 640-655.
Jonson, E. P., McGuire, L., Rasel, S., \& Cooper, B. (2020). Older boards are better boards, so beware of diversity targets. Journal of Management \& Organization, 26(1), 15-28.

Katmon, N., Mohamad, Z. Z., Norwani, N. M., \& Al Farooque, O. (2019). Comprehensive board diversity and quality of corporate social responsibility disclosure: Evidence from an emerging market. Journal of Business Ethics, 157(2), 447-481.

Khan, A. (1999). Ethnicity, Islam and national identity in Pakistan. South Asia: Journal of South Asian Studies, 22, 167-182.

Khan, A., Muttakin, M. B., \& Siddiqui, J. (2013). Corporate governance and corporate social responsibility disclosures: Evidence from an emerging economy. Journal of Business Ethics, 114(2), 207-223.

Khan, I., Khan, I., \& Saeed, B. B. (2019a). Does board diversity affect the quality of corporate social responsibility disclosure? Evidence from Pakistan. Corporate Social Responsibility and Environmental Management, 26(6), 1371-1381.

Khan, I., Khan, I., \& Senturk, I. (2019b). Board diversity and quality of CSR disclosure: Evidence from Pakistan. Corporate Governance: International Journal of Business in Society, 19(6), 1187-1203.

Khan, M. H. U. Z. (2010). The effect of corporate governance elements on corporate social responsibility (CSR) reporting: Empirical evidence from private commercial banks of Bangladesh. International Journal of Law and Management, 52(2), 82-109.

Kim, S. (2003). Research paradigms in organizational learning and performance: Competing modes of inquiry. Information Technology, Learning and Performance Journal, 21(1), 9-18.

King, A. W. (2007). Disentangling inter-firm and intrafirm causal ambiguity: A conceptual model of causal ambiguity and sustainable competitive advantage. Academy of Management Review, 32(1), 156-178.

Kiviet, J. F., \& Feng, Q. (2012). Exploiting strong instruments unduly neglected by standard GMM. Retrieved from http:// www.eco.uc3m.es/temp/FK11a.pdf. 
Kolk, A., \& Pinkse, J. (2010). The integration of corporate governance in corporate social responsibility disclosures. Corporate Social Responsibility and Environmental Management, 17(1), 15-26.

Krauss, S. E. (2005). Research paradigms and meaning making: A primer. The Qualitative Report, 10(4), 758-770.

Kuhn, T. S. (1977). Objectivity, value judgment, and theory choice. In A. Bird, \& J. Ladyman (Ed.), Arguing About Science (p. 74-86). New York: Routledge.

Lan, Y., Wang, L., \& Zhang, X. (2013). Determinants and features of voluntary disclosure in the Chinese stock market. China Journal of Accounting Research, 6(4), 265-285.

Liang, L. -W., Chang, H. -Y., \& Liu, J. -H. (2020). Does corporate social responsibility make banks more cost efficient? Taiwan Journal of Economics, 106, 107-146.

Mackenzie, N., \& Knipe, S. (2006). Research dilemmas: Paradigms, methods and methodology. Issues in Educational Research, 16(2), 193-205.

Majeed, G. (2010). Ethnicity and ethnic conflict in Pakistan. Journal of Political Studies, 17(2), 51-63.

Manyaga, F., \& Taha, M. (2020). Linking firm performance with board diversity: A literature review. Bussecon Review of Finance \& Banking, 2(1), 10-18.

Marczyk, G., \& DeMatteo, D. (2005). Essentials of research design and methodology. Hoboken, N.J: John Wiley \& Sons.

Maurer, C. C., Bansal, P., \& Crossan, M. M. (2011). Creating economic value through social values: Introducing a culturally informed resource-based view. Organization Science, 22(2), 432-448.

McGregor, S. L., \& Murnane, J. A. (2010). Paradigm, methodology and method: Intellectual integrity in consumer scholarship. International journal of consumer studies, 34(4), 419-427.

Mehjabeen, M., \& Bukth, T. (2020). Comparative analysis of the dominant themes in CSR reporting discourse in Bangladesh: A structured literature review. Accounting and Finance Review, 5 (1), 1 - 14.
Michelon, G., \& Parbonetti, A. (2012). The effect of corporate governance on sustainability disclosure. Journal of Management Governance, 16(3), 477-509.

Muttakin, M. B., Khan, A., \& Subramaniam, N. (2015). Firm characteristics, board diversity and corporate social responsibility: Evidence from Bangladesh. Pacific Accounting Review, 27(3), 353-372.

Nour, A. I., Sharabati, A. A. A., \& Hammad, K. M. (2020). Corporate governance and corporate social responsibility disclosure. International Journal of Sustainable Entrepreneurship and Corporate Social Responsibility, 5(1), 20-41.

Olthuis, B. R., \& van den Oever, K. F. (2020). The board of directors and CSR: How does ideological diversity on the board impact CSR?. Journal of Cleaner Production, 251(119532).

Pakistan Stock Exchange. (2018). Annual Report of Amman stock exchange 2010-2018. Retrieved from https://dps.psx.com.pk/.

Peteraf, M. A., \& Bergen, M. E. (2003). Scanning dynamic competitive landscapes: A market based and resource-based framework. Strategic Management Journal, 24, 1027-1041.

Platonova, E., Asutay, M., Dixon, R., \& Mohammad, S. (2018). The impact of corporate social responsibility disclosure on financial performance: Evidence from the GCC Islamic banking sector. Journal of Business Ethics, 151(2), 451-471.

Ponterotto, J. G. (2005). Qualitative research in counseling psychology: A primer on research paradigms and philosophy of science. Journal of Counseling Psychology, 52(2), 126.

Post, C., Rahman, N., \& Rubow, E. (2011). Green governance: Boards of directors' composition and environmental corporate social responsibility. Business and Society, 50(1), 189-223.

Pucheta-Martínez, M. C., \& Gallego-Álvarez, I. (2019). An international approach of the relationship between board attributes and the disclosure of corporate social responsibility issues. Corporate Social Responsibility and Environmental Management, 26(3), 612-627. 
Rao, K., \& Tilt, C. (2016a). Board composition and corporate social responsibility: The role of diversity, gender, strategy and decision making. Journal of Business Ethics, 138(2), 327-347.

Rao, K., \& Tilt, C. (2016b). Board diversity and CSR reporting: An Australian study. Meditari Accountancy Research, 24(3), 182-210.

Roberts, M. R., \& Whited, T. M. (2013). Endogeneity in empirical corporate finance. In Handbook of the Economics of Finance, 2(1). 493-572).

Roodman, D. (2009a). How to do xtabond2: An introduction to difference and system GMM in Stata. The Stata Journal, 9(1), 86-136.

Roodman, D. (2009b). A note on the theme of too many instruments. Oxford Bulletin of Economics and Statistics, 71(1), 135-158.

Said, R., Zainuddin, Y. H., \& Haron, H. (2009). The relationship between corporate social responsibility disclosure and corporate governance characteristics in Malaysian public listed companies. Social Responsibility Journal, 5(2), 212-226.

Saleh, M., Zulkifli, N., \& Muhamad, R. (2010). Corporate social responsibility disclosure and its relation on institutional ownership. Managerial Auditing Journal, 25(6), 591-613.

Sarantakos, S. (2005). Social Research (3rd ed.). Melbourne: Macmillan Education.

Saunders, M., Lewis, P., \& Thornhill, A. (2009). Research methods for business students. New York: Pearson education.

Securities and Exchange Commission of Pakistan. (2017). Listed companies (code of corporate governance) regulations. Islamabad: SECP.

Sieber, S. D. (1973). The integration of fieldwork and survey methods. American journal of sociology, 78(6), 1335-1359.

Silverman, D. (2000). Doing qualitative research: A practical handbook. London, Thousand Oaks, New Delhi: Sage Publications.
Soto, M. (2009). System GMM estimation with a small sample (Working Paper n. 780.08). Retrieved from https:// www.recercat.cat/handle/2072/41978.

Teece, D. J., Pisano, G., \& Shuen, A. (1997). Dynamic capabilities and strategic management. Strategic Management Journal, 18(7), 509-533.

Triguero-Sánchez, R., Pena-Vinces, J., \& Guillen, J. (2018). How to improve firm performance through employee diversity and organizational culture. Review of Business Management, 20(3), 378-400.

Upadhyay, A., \& Zeng, H. (2014). Gender and ethnic diversity on boards and corporate information environment. Journal of Business Research, 67(11), 2456-2463.

Vulliamy, G. (1990). How can qualitative research contribute to educational policy-making in developing countries?. International Journal of Educational Development, 10(2-3), 151-156.

Walter, M. (2006). Social science methods: An Australian perspective. Oxford, New York: Oxford University Press.

Wellalage, N., Locke, S., \& Acharya, S. (2018). Does the composition of boards of directors impact on CSR scores? Social Responsibility Journal, 14(3), 651-669.

Wernerfelt, B. (1984). A resource-based view of the firm. Strategic Management Journal, 5(2), 171-180.

Wood, D. J. (1991). Corporate social performance revisited. Academy of Management Review, 16, 691-718.

Wooldridge, J. M. (2002). Inverse probability weighted M-estimators for sample selection, attrition, and stratification. Portuguese Economic Journal, 1(2), 117-139.

Yu, Y., \& Choi, Y. (2016). Stakeholder pressure and CSR adoption: The mediating role of organizational culture for Chinese companies. The Social Science Journal, 53(2), 226-235.

Yusof, S. M., Nordin, N. A., Jais, M., \& Sahari, S. (2019). Impact of board diversity on corporate social responsibility (CSR) on Malaysian public listed companies. International Journal of Academic Research in Business and Social Sciences, 9(7), 1049 - 1069 . 
Zhang, J. Q., Zhu, H., \& Ding, H. B. (2013). Board composition and corporate social responsibility: An empirical investigation in the post Sarbanes-Oxley era. Journal of Business Ethics, 114(3), 381-392.
Zwikael, O., Elias, A. A., \& Ahn, M. J. (2012). Stakeholder collaboration and engagement in virtual projects. International Journal of Networking and Virtual Organizations, 10(2), 117-136. 


\section{Appendix A}

\section{Quality of Corporate Social Responsibility Index}

\begin{tabular}{|c|c|c|c|c|c|c|}
\hline \multirow{2}{*}{ CSR activity } & \multicolumn{6}{|c|}{ Years } \\
\hline & 2010 & 2011 & $\ldots$ & $\ldots$ & $\ldots$ & 2018 \\
\hline \multicolumn{7}{|l|}{ 1. Employee relations } \\
\hline \multicolumn{7}{|l|}{ 1. Employee health and safety } \\
\hline \multicolumn{7}{|l|}{$\begin{array}{l}\text { 2. Training and education and employee } \\
\text { benefits }\end{array}$} \\
\hline \multicolumn{7}{|l|}{ 4. Employees' profile } \\
\hline \multicolumn{7}{|l|}{ 5. Share options for employees } \\
\hline \multicolumn{7}{|l|}{ 6. Health and safety award } \\
\hline \multicolumn{7}{|l|}{ Subtotal of disclosure (a) } \\
\hline \multicolumn{7}{|l|}{ 2.Community involvement } \\
\hline \multicolumn{7}{|l|}{ 1. Cash donations program } \\
\hline \multicolumn{7}{|l|}{ 2. Charity program } \\
\hline \multicolumn{7}{|l|}{ 3. Scholarship program } \\
\hline \multicolumn{7}{|l|}{ 4. Sponsor for sport activities } \\
\hline \multicolumn{7}{|l|}{ 5. Supporting national pride } \\
\hline \multicolumn{7}{|l|}{ 6. Public/private projects } \\
\hline \multicolumn{7}{|l|}{ Subtotal of disclosure (b) } \\
\hline \multicolumn{7}{|l|}{ 3. Product } \\
\hline \multicolumn{7}{|l|}{$\begin{array}{l}\text { 1. Product/service improvement and } \\
\text { development }\end{array}$} \\
\hline \multicolumn{7}{|l|}{ 2. Product/service safety } \\
\hline \multicolumn{7}{|l|}{ 3. Product/service quality } \\
\hline \multicolumn{7}{|l|}{ 4. Customer services } \\
\hline \multicolumn{7}{|l|}{ Subtotal of disclosure (c) } \\
\hline \multicolumn{7}{|l|}{ 4. Environment } \\
\hline \multicolumn{7}{|l|}{ 1. Pollution control } \\
\hline \multicolumn{7}{|l|}{ 2. Prevention or reparation program } \\
\hline \multicolumn{7}{|l|}{$\begin{array}{l}\text { 3. Conservation/waste management and } \\
\text { recycling }\end{array}$} \\
\hline \multicolumn{7}{|l|}{ 4. Award in environmental program } \\
\hline \multicolumn{7}{|l|}{ Subtotal of disclosure $(\mathrm{d})$} \\
\hline Total of QCSR score/60) & & & & & & \\
\hline
\end{tabular}




\section{Conflicts of interest:}

The authors have no conflict of interest to declare

\section{Copyrights:}

RBGN owns the copyrights of this published content

\section{Plagiarism analysis}

RBGN performs plagiarism analysis on all its articles at the time of submission and after approval of the manuscript using the iThenticate tool.

\section{Authors:}

1. Ismail Khan, Department of Management, Sunway University Business School, Selangor, Malaysia.

E-mail: ismailwazir048@gmail.com

2. Iftikhar Khan, Management Sciences, COMSATS University Islamabad, Abbottabad, Pakistan.

E-mail: iftikharmarwat792@gmail.com

3. Muhammad Asim Afridi, PhD Economics, COMSATS University Islamabad, Abbottabad, Pakistan.

E-mail: asimafridi@cuiatd.edu.pk

\section{Authors' Contributions}

1. Ismail Khan: Definition of research problem; Development of hypotheses or research questions (empirical studies); Development of theoretical propositions (theoretical work); Theoretical foundation/literature review; Data collection; Statistical analysis; Critical revision of the manuscript; Manuscript writing.

2. Iftikhar Khan: Theoretical foundation/literature review; Data collection; Statistical analysis; Manuscript writing.

3. Muhammad Asim Afridi: Definition of research problem; Development of hypotheses or research questions (empirical studies); Development of theoretical propositions (theoretical work); Definition of methodological procedures; Analysis and interpretation of data; Critical revision of the manuscript. 